\title{
The demise of Joshua according to
}

\section{Josephus}

\author{
Christopher T Begg' \\ The Catholic University of America \\ Washington, DC (USA)
}

\begin{abstract}
This article focuses on Josephus' account of the end of Joshua in his Ant. 5.115-119. It offers a detailed comparison between that account and its biblical source (Jos 23-24) on the one hand, and two other postbiblical narrations of Joshua's demise, that is those of Pseudo-Philo in Liber Antiquitatum Biblicarum 23-24 and the "Samaritan Chronicle No. II," on the other. As compared with Joshua 23-24, Josephus' version appears highly abbreviated, leaving aside, for example, the whole of Joshua 23 as well as 24:1628, 31-32, even while also introducing various new elements. Josephus shares his non-reproduction of Joshua 23 and 24:31-32 with Pseudo-Philo and the Chronicle, for example, but deviates from these other witnesses in his downplaying of the role/activities of the dying Joshua.
\end{abstract}

\section{INTRODUCTION}

The Book of Joshua concludes, in chapters 23-24, with two, back-to-back farewell discourses by the protagonist $(23: 1-16 ; 24: 1-15),{ }^{2}$ an exchange between him and the people (24:16-24), a series of initiatives by Joshua (24:25-28), and finally a complex of notices (24:29-33) concerning the death and burial of Joshua (vv 29-30), Israel's fidelity during Joshua's lifetime (v 31), the burial of Joseph's bones ( $v 32$ ), and the death and burial of the priest Eleazar (v 33). Already in the two major ancient textual witnesses for the Book

\footnotetext{
${ }^{1}$ Dr C T Begg, Professor at the School of Theology and Religious Studies, The Catholic University of America (Washington, DC) and editor of Old Testament Abstracts (OTA), is a research associate of Prof Dr Dirk J Human, Programme Manager, Biblical and Religious Studies, Faculty of Theology, University of Pretoria.

${ }^{2}$ This duplication of Joshua's last word has given rise to numerous source/redactional hypotheses about the two speeches' origin and relationship to each other. See, e.g., the evolving views of Noth (1981:102-103, n 15).
} 


\section{The demise of Joshua according to Josephus}

of Joshua, i.e. $\mathrm{MT}^{3}$ and $\mathrm{LXX},{ }^{4}$ one finds marked differences in their respective versions of the two chapters (Rofé 1982; Rösel 2002). In this essay I wish to focus on a postbiblical presentation of Joshua's demise, i.e. that given by Josephus in his Antiquitates Judaicae (hereafter Ant.) 5.115-119 (Marcus, 1934:52-57). ${ }^{5}$ My study of the Josephan passage will proceed in two stages. I shall first compare this with Joshua 23-24 (as represented by MT and LXX) in terms of, e.g., its context, biblical text-form(s) used, degree of adherence to the Vorlage's content and sequence, and distinctive features. Thereafter, I shall compare Josephus' account with two other rewritings of Joshua 23-24, i.e. Pseudo-Philo's Liber Biblicarum Antiquitatum (hereafter L.A.B.) 23-24 and the "Samaritan Chronicle No. II," with a view to determining its similarities and differences with these other witnesses to the traditio-historical trajectory initiated by the biblical text.

\section{ANT. 5.115-119 AND JOSHUA 23-24}

Josephus gives his highly compressed version of Joshua 23-24 in Ant. 5.115119. In his presentation - as in the Bible itself - this account of Joshua's end is immediately preceded by the episode of the Transjordanian altar (Jos 22:10-34// Ant. 5.100-114 ${ }^{6}$ ). The historian rounds off that episode and makes the transition to what follows via the (biblically unparalleled) notice "Thereafter, having dismissed the multitude to their several provinces, Joshua himself abode at Sikima." 7 Thereafter (5.115b), Josephus conflates data drawn from the respective introductions (23:1-2a; $24: 1-2 a)$ of the biblical Joshua's two separate farewell discourses as a lead-in to the single such discourse he will relate. This conflate introduction reads: "Twenty years later, ${ }^{8}$

\footnotetext{
${ }^{3}$ Joshua 23-24 is not extant in the Qumran fragments of the book.

${ }^{4}$ For the LXX (Codex Vaticanus = B) text of Joshua 23-24, I use Brooke \& Maclean (1917:775-783). I have likewise consulted the French translation of and notes on this in Moatti-Fine (1996:227-240). Closely aligned with LXX Joshua 23-24 is the Vetus Latina (hereafter VL) text of the passage for which I use Robert (1900:100-105).

${ }^{5}$ On this passage, see further the text, translation, and notes of Nodet $\left(1995: 143-144^{\star}\right)$ and the annotated translation of Begg (2005:28-29). On the Josephan Joshua overall, see Feldman (1998:433-460) and Spilsbury (1998:147-153).

${ }^{6}$ On this text (and its parallel in L.A.B. 22.1-8), see Begg (1997).

${ }^{7}$ In the paragraphing of Marcus this notice constitutes the opening of Ant. 5.115, while in that of Nodet it represents the conclusion of 5.114. I follow Marcus's paragraphing here.

${ }^{8}$ With this chronological indication Josephus renders more precise the opening words of Jos 23:1 ("a long time afterwards," i.e. following the altar episode of Jos 22). The precision has in view the chronology of Joshua's activity Josephus will give in Ant. 5.117. He has no equivalent to the continuation of the biblical time reference in $23: 1$ a, i.e. "... when the Lord had given rest to Israel from all their enemies round about."
} 
in extreme old age, ${ }^{9}$ having sent for the chief notables of the cities (Tous ' $\varepsilon \pi$ '

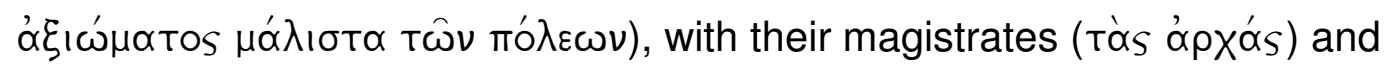

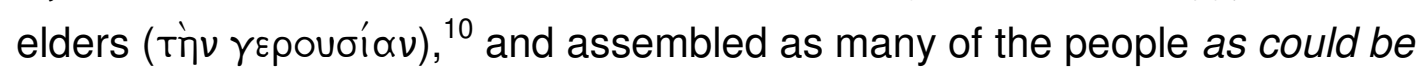
collected, ${ }^{11}$ he, on their coming ....." ${ }^{12}$

For all their differences of detail, Josephus' farewell discourses as cited in Jos 23:2b-16 and 24:2-14 both consist of two basic elements, i.e. reminiscences of the Lord's benefactions to the people and admonitions about their remaining faithful to him. The same two components are likewise present in the single, highly compressed and generalized speech that Josephus attributes to Joshua in 5.115c-116a:

$(5.115 \mathrm{c}) \ldots$ [he] recalled to them the benefactions of God

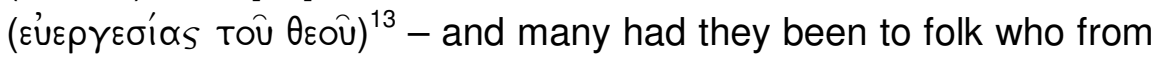
low estate had advanced to that pitch of glory and affluence ( $\delta \delta^{\prime} \xi \eta s$

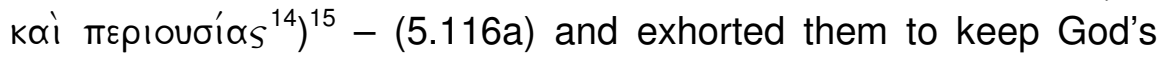

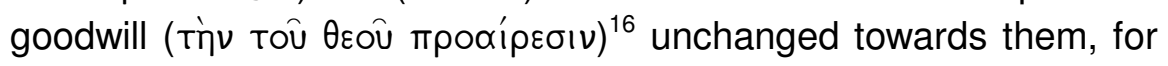

\footnotetext{
${ }^{9}$ Compare Joshua 23:1b “... (when) Joshua was old and well advanced in years.”

${ }^{10}$ This grouping, whose designation recalls the Jewish council of postexilic times, figures prominently as a consultative body in Josephus' version of the Book of Joshua in Ant. 5.1119. On it, see Goodblatt (1994:30-34, 90-99) and Mason (2003:573-581). With Josephus' above, three-member listing of the Israelite officials, compare the four-member lists of MT Jos

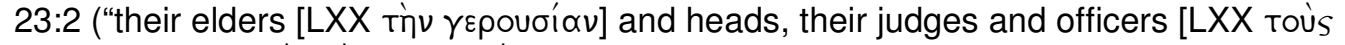

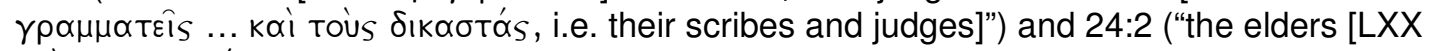

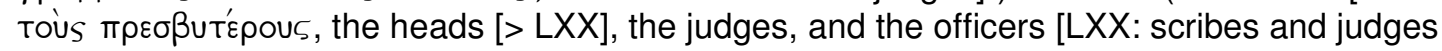
as in 23:2] of Israel").

${ }^{11}$ Josephus' formulation qualifies the biblical references to Joshua's summoning "all Israel" (23:2a)/ "all the tribes of Israel" (24:2a) in view of the vast numbers involved and the need for haste, given Joshua's advanced age. (I italicize elements of Josephus' text like the above which lack a clear biblical counterpart.) Jos $23: 2$ does not specify the site of the assembly called by Joshua, while 24:1a has him summon people and leaders to Shechem (so MT; LXX: Shiloh). Josephus' immediately preceding reference to Joshua's residing at "Sikima" suggests that the assembly was convened at the same site, à la MT 24:1a.

${ }^{12}$ Compare Jos 24:1b: "and they [the people and leaders cited in 24:1a] presented themselves before God." The sense of the biblical phrase "before God" here is unclear and has no equivalent in Josephus.

${ }^{13}$ This phrase occurs only here in Josephus.

${ }^{14}$ This collocation occurs only here in Josephus.

${ }^{15}$ The divine "benefactions" to which the Josephan Joshua alludes here are spelled out by his biblical namesake in Jos 23:3-5, 9-10, 14 (the Lord's ongoing clearing of the land for Israel's occupation) and 24:2-12 (the Lord's initiatives on behalf of the people from the time of Abraham down to their present establishment in the land).

${ }^{16}$ This expression occurs also in Ant. 4.24, 105; 8.223.
} 


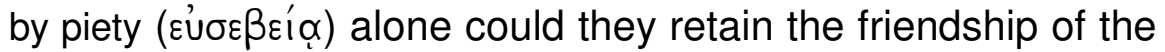
Deity ( фí̀ov ... Tò $\left.\theta \varepsilon i ̂ \nu^{17}\right) .^{18}$

Joshua's second farewell discourse (24:2-15) leads into an extended, quite repetitious dialogue between himself and the people (24:16-24) on the (im-) possibility of their "serving" the Lord. Thereupon, Joshua (24:25-28) undertakes a series of concluding initiatives: he makes a covenant with the people and lays down "statutes and ordinances" for them ( $v 25$ ), writes "these words" in "the book of the law of the God," erects a great stone beneath "the oak in the sanctuary of the Lord" (v 26), declaring this to be a "witness" to the words the Lord has spoken to the people in case they prove unfaithful ( $v 28 a)$, and finally dismisses the people ( $v 28 b$ ). Josephus has no equivalent to the entire sequence $24: 16-28 .{ }^{19}$ Instead, he supplies (5.116b) his own conclusion to Joshua's (single) discourse, this consisting of a rationale for his delivering a discourse at this moment and an appended appeal that his hearers pay heed to his words. It reads: "It behoved him, he said, on the eve of departure from life, to leave them such admonition, and he besought them to bear his exhortation in their memory."20

As noted above, Joshua 24 concludes with a series of narrative notices, vv 29-33. In this segment MT and LXX evidence numerous and noteworthy differences. Such differences emerge already at the start of the complex where LXX reproduces the sequence of MT 24:29-30 (death and burial of Joshua) and 31 (the Israelites remain faithful to the Lord in the lifetime of Joshua and the elders who outlive him) in reverse order. Lacking a

\footnotetext{
${ }^{17}$ With this reference to God as the people's "friend," compare Ant. 6.20 where Samuel,

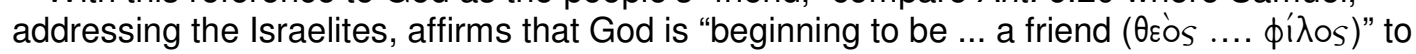
them.

${ }^{18}$ This hortatory component of Joshua's speech synthesizes the leader's expansive admonitions and warnings to his hearers in Jos 23:6-8, 12-13, 15-16 and 24:14-15 (here Joshua offers the people the choice of serving the Lord or others gods, while declaring his own and his household's intention of serving the Lord).
}

\footnotetext{
${ }^{19}$ Various considerations may help account for his non-utilization of this material: Joshua's affirmation about the impossibility of the people's serving the Lord (see 24:19) calls into question the basic biblical presupposition that people can indeed serve the Lord if they choose; the references to Joshua's covenant-making and law-giving roles (vv 25-26) might seem to put him on a par with Moses, Israel's supreme covenantal intermediary and legislator; a sanctuary of the Lord at Shechem (vv 25-26a) has not been previously been mentioned; and the notion of an inanimate object, i.e. "the great stone" of $v 26$, "hearing" and serving as a witness (v 27) could appear too "primitive" for Josephus' cultivated Greco-Roman readers.

${ }^{20}$ The speech Josephus attributes to Joshua in $5.115 c-116$, in contrast to its biblical counterparts, $23: 2 b-16$ and 24:2-15, is formulated throughout in indirect discourse. On Josephus' tendency to recast biblical direct-discourse speeches in indirect discourse, see Begg (1993:12-13, n 38).
} 
counterpart to 24:31, Josephus (5.117a), in the line of MT Joshua 24, attaches his notice on Joshua's death (// 24:29) directly to the conclusion of the leader's speech (5.116b): "And so, after this address to the assembled company, ${ }^{21}$ he died, having lived one hundred and ten years ....". ${ }^{22}$ Biblically, mention of Joshua's death and life-span (24:29) is followed immediately by the notice of his burial in his Ephraimite inheritance (24:30). Josephus' rendering of these items, in $5.117 \mathrm{a}$ and $119 \mathrm{a}$, respectively, is separated by an extended segment $(5.117 \mathrm{~b}-118)$ of his own composition. Within this interlude, in turn, one may distinguish two components. Of these, the first (5.117b) supplies further particulars concerning the last 65 years of Joshua's life: “... of which he had passed forty in the company of Moses $^{23}$ receiving profitable

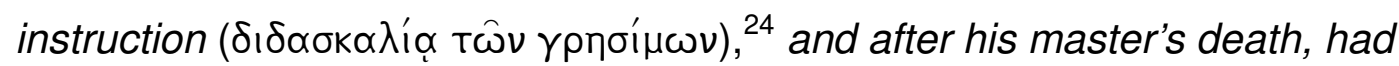

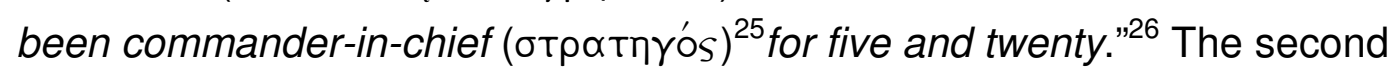
part of Josephus' insertion (5.118) consists of the following eulogy of the deceased leader:

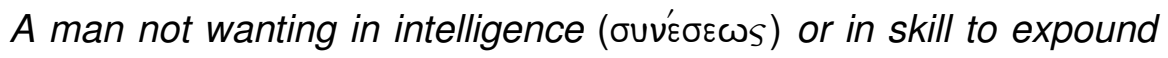

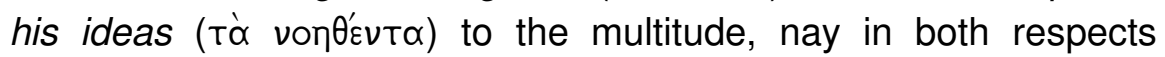
supreme ("akpos), in action and perils he was stout-hearted and

\footnotetext{
${ }^{21}$ Josephus' formulation underscores the connection between Joshua's just concluded speech and his following death. Compare the vague transitional phrase at the start of 24:29: "after these things [or words, MT הדברים] (LXX has simply the demonstrative adjective

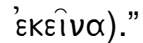

${ }^{22}$ This is the figure for Joshua's age at death found in both MT and LXX Joshua.

${ }^{23}$ Josephus' figure for Joshua's apprenticeship corresponds to the traditional duration of the desert wanderings (see Num 14:33// Ant. 3.314), which Josephus here represents as coinciding with the Moses-Joshua association.
}

${ }^{24}$ This expression occurs only here in Josephus. The phrase serves to underscore the ongoing primacy of Moses in the relationship between him and Joshua: throughout their relationship, Moses was the teacher, Joshua the learner.

${ }^{25}$ As Feldman (1998:448 and $n$ 8) points out, Josephus introduces this (non-biblical) title for Joshua no less than ten times in the course of his presentation of him.

${ }^{26}$ Josephus arrives at this total for Joshua's tenure as leader by combining figures previously given by him, i.e. Ant. 5.68 (the five-year campaign led by Joshua has resulted in the virtual elimination of the Canaanites) and $5.115 \mathrm{~b}$ (see above; Joshua lives on twenty years at Shechem). Elsewhere in Jewish tradition one finds divergent indications concerning the duration of Joshua's leadership. According to S. 'Olam Rab. 12.1 this lasted 20 years, while Eupolemus (apud Eusebius, Praep. Ev. 9.30.1) credits him with 30 years of prophesying in succession to Moses. See also below on L.A.B. 24.6 where Pseudo-Philo alludes to the "forty years" during which Joshua led Israel. 


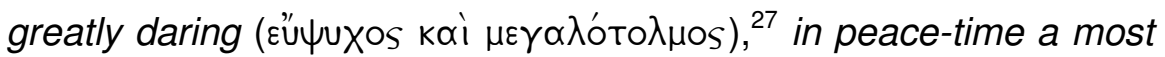
dexterous ( $\delta \varepsilon \xi ı \omega t \alpha T o s)$ director of affairs, adapting himself admirably to every occasion. ${ }^{28}$

Having amplified the death notice of Jos 24:29 with the above remarks, Josephus finally comes (5.119a) to present his (abbreviated) version of the mention of the hero's burial of Jos 24:30. From the biblical indications concerning the site, he extracts two elements as follows: "He was buried in the city of Thamna $(\Theta \alpha \mu \nu \hat{\alpha})$ of the tribe of Ephraim." ${ }^{29}$

The continuation of the series of concluding notices in Joshua 24 (MT) cites first the (temporary) fidelity of the Israelites ( $v 31$ ), and then the burial of the bones of Joseph that had been brought up from Egypt ( $v 32$ ). Josephus has no parallel to either of these items. ${ }^{30}$ Instead, he proceeds immediately to relate $(5.119 b)$ the contemporaneous death and burial of Joshua's sacerdotal counterpart, i.e. Eleazar: "About the same time ${ }^{31}$ died also Eleazar the high

\footnotetext{
${ }^{27}$ The above collocation occurs once elsewhere in Josephus, i.e. in Ant. 6.347 (in the context of a reflection on Saul's courage in going into battle without any hope of emerging alive).

${ }^{28}$ Josephus' above eulogy of the deceased Joshua's intellectual, oratorical, military, and political qualities echoes his initial characterization of him at the moment of his choice by Moses in Ant. 3.49: "a man of extreme courage, valiant in the endurance of toil, highly gifted in intellect (voīool) and speech, and withal one who worshipped God with a singular piety which he had learnt from Moses and who was held in high esteem by the Hebrews." Such inserted eulogies of leading figures are a hallmark of Josephus' rewriting of biblical history; they serve to remind Greco-Roman readers that the Jews did have great men of their own contrary to what their detractors claimed. On the point, see Feldman (1998:74-131).
}

${ }^{29}$ Compare Jos 24:30: "And they buried him in his own inheritance at Timnath-serah (LXX $\Theta \alpha \mu \nu \alpha \theta \alpha \sigma \alpha \times \propto \rho \rho \alpha)$, which is in the hill country of Ephraim, north of the mountain of Gash." Josephus has no equivalent to the long plus attached to the notice on Joshua's burial in LXX (and $V L$ ) according to which the stone knives used by Joshua to circumcise the Israelites at Gilgal (see Jos 5:2-9 - a passage not reproduced by Josephus) were buried in the tomb with him. The historian likewise makes no allusion to the discussion, attested by various midrashic-rabbinic sources (b. Šabb. 105b; Midr. Sam. 23.7; Midr. Ruth Rab. proem 2; Midr. Qoh. Rab. 7.1.4), concerning the Israelites' failure, due to their preoccupation with their own pursuits, to give Joshua proper mourning and God's resultant displeasure. As we shall see, Pseudo-Philo (L.A.B. 24.6) provides an implicit refutation of this accusation by attributing to the people an extended lamentation for Joshua, prior to their burial of him.

\footnotetext{
${ }^{30}$ His lack of parallel to Jos 24:32 is especially surprising in that earlier he does reproduce the biblical notices that prepare this, i.e. Gn 50:20 (// Ant. 2.200a: the dying Joseph's insistence that his bones eventually be buried in Canaan) and Exod 13:19 (// Ant. 3.319b: the departing Israelites take Joseph's bones with them). Perhaps, Josephus opted to omit the content of 24:32 lest the burials of the contemporaries Joshua and Eleazar be overshadowed (and "interrupted" - as they are in Joshua 24) by that of a figure of the distant past.

${ }^{31}$ This transitional phrase, underscoring the simultaneity of the deaths of Israel's two leaders, has a certain equivalent in the opening plus of LXX 24:33, i.e. "and it happened after this."
} 


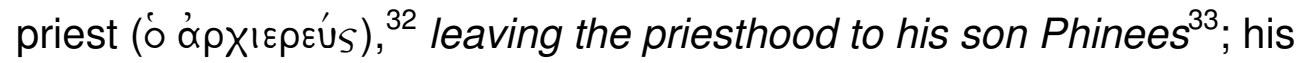

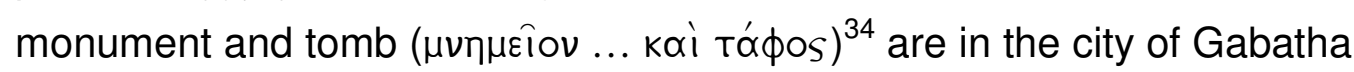
$(\Gamma \alpha \beta \alpha \theta \hat{\alpha}) .{ }^{, 35}$

Having completed my detailed comparison of Ant. 5.115-119 and Joshua 23-24, I shall now summarize my findings on the questions concerning their relationship I posed at the start. Josephus' version of Joshua 23-24, first of all, stands in its biblical position, i.e. after the Transjordanian altar episode (Joshua 22// Ant. 5.93-114) and prior to the tribal initiatives related in Judges 1// Ant. 5.120-131. ${ }^{36}$ As for the text-critical affinities of Ant. 5.115-119, our results were mixed. The historian agrees with MT 24:1, for example, in his (implicit) localizing of Joshua' address at Shechem rather than Shiloh (see $\mathrm{n}$ 12), as also in his lack of equivalent to the LXX plus following 24:30 (the circumcision knives buried with Joshua; see $n$ 28). On the other hand, he also evidences affinities with the wording of LXX 24:33 (see nn 30,31) and with its subsequent plus for what concerns the mention of the succession of Phineas (see $n$ 32) - even while having no equivalent to the remaining content of that

\footnotetext{
${ }^{32}$ Josephus' ascription of this title to Eleazar has a counterpart in the plus of LXX 24:33 (MT calls him simply "the son of Aaron").
}

${ }^{33}$ This reference to Phineas' succession, unparalleled in MT Jos 24:33 (where Eleazar is buried "at Gibeah, the town of Phineas his son"), does have a counterpart in the long plus that follows 24:33 in LXX (see $n$ 34). Josephus' utilization of the LXX element at this juncture makes sense, given that in the immediately following 5.120 he will highlight the initiative of Phineas in assigning military leadership against the surviving Cannanites to the tribe of Judah (compare Jdg 1:1-2 where Phineas is not mentioned). On the figure of Phineas in biblical and later Jewish tradition, see Feldman (2003).

${ }^{34}$ This collocation occurs only here in Josephus.

${ }^{35}$ Josephus simplifies the indications concerning Eleazar's burial place given in 24:33: "at Gibeah (LXX $\Gamma \alpha \beta \alpha \alpha \alpha \rho)$, the town of Phineas his son, which had been given to him in the hill country of Ephraim." Josephus has no equivalent (although see $n$ 32) to the long LXX plus which follows the notice on Eleazar's death and burial in 24:33. This reads: "On that day the sons of Israel took the ark of God and passed it around among themselves and Phineas became priest in place of Eleazar his father until he died and was buried in Gabaar that was his own. Then the sons of Israel went each to his own place and town. And the sons of Israel worshiped Astarte and the Astaroth and the gods of the surrounding nations. And the Lord handed them over into the hand of Eglom, king of Moab, and he oppressed them for eighteen years (see Jdg 3:12-13)."

${ }^{36}$ Elsewhere, on occasion, Josephus does notably deviate from the biblical sequence. Thus, e.g., he transfers the two concluding narrations of the Book of Judges, i.e. chapters 17-18 (Micah's idol and the founding of the sanctuary of Dn) and 19-21 (the Gibeah outrage and the resultant near destruction of the tribe of Benjamin) to the beginning of his own version of Judges, likewise reversing the sequence of the two segments; see Ant. 5.136-174 (// Judges 19-21) and 5.175-178 (// Judges 17-18). 


\section{The demise of Joshua according to Josephus}

plus (see $n$ 34). ${ }^{37}$ On the further question of Josephus' "fidelity" to Joshua 2324, it has emerged that Ant. 5.115-119 is an instance where he does take considerable liberties with the content of his Vorlage. Those liberties concern above all his drastic abbreviation of the biblical material. In particular, Josephus conflates into one the two separate farewell discourses of Jos 23:2b-16 and 24:2-15. In addition, he offers no parallel to the material of Jos 24:16-28 (see n 18), 31-32 (the Israelites' service of the Lord and the burial of Joseph's bones). My final above question asked about the presence of distinctive features in Josephus' rendering of Joshua 23-24. Its brevity notwithstanding, Ant. 5.115-119 does, we discovered, evidence a whole series of elements that derive from Josephus himself: Joshua's twenty-year residence at Shechem (5.115a), the concluding words of his (single) discourse $(5.116 \mathrm{~b})$, the chronological indications concerning his career in $5.117 \mathrm{~b}$ and the eulogy of him in 5.118 .

The distinctiveness of Josephus' version of Joshua 23-24 stands out, however, not only in relation to the biblical text, but also to the other abovementioned rewritings of that text, i.e. those of Pseudo-Philo and the Samaritan Chronicle No. II. Accordingly, I turn to a summary comparison between Ant. 5.115-119 and these two post-biblical presentations of Joshua's end. ${ }^{38}$

\section{JOSEPHUS AND PSEUDO-PHILO}

Pseudo-Philo, like the Bible and Josephus, relates (L.A.B. 23-24) the events surrounding Joshua's demise subsequent to his account of the Transjordanian altar episode (L.A.B. 22// Jos 22:10-34// Ant. 5.100-114). Within the extended sequence of L.A.B. $23-24,{ }^{39}$ one might distinguish three main components: an initial, lengthy exchange between Joshua and the assembled people (23.1-

\footnotetext{
${ }^{37}$ On the question of Josephus' text of the Book of Joshua overall, see Nodet (1995:xiii), who in agreement with earlier authors, avers that the historian's rewriting of the book in Ant. 5.1119 is based, in first place, on a Hebrew text that "was much closer" to our MT than to the LXX.

${ }^{38}$ Space constraints do not allow me to discuss either L.A.B. 23-24 or the relevant passage of the Samaritan Chronicle No. II in detail, as I did for Ant. 5.115-119. My purpose rather is simply to highlight salient differences and similarities between the former and the latter texts in their respective rewritings of Joshua 23-24.

${ }^{39}$ For the Latin text of this passage I use Jacobson (1996, 1:33-36) and for the English translation - which involves certain emendations of the Latin text of Harrington printed by Jacobson - (1:129-132). On L.A.B. 23-24, see the more detailed comments of Dietzfelbinger (1975:163-168); Harrington Perrot \& Bogaert (1976, 2:144-150); Murphy (1993:107-115); and Jacobson (1996, 2:711-735); see also Reinmuth (2002) on Pseudo-Philo's overall presentation of Joshua in L.A.B. 20-24. On the controverted question of the biblical text used by Pseudo-Philo, see Jacobson (1996, 2:255) who concludes "... there is no compelling evidence that his text was very different from MT."
} 
14), a second, shorter dialogue between the two parties (24.1-3), and a series of notices on Joshua's death and burial (24.4-6).

L.A.B. 23.1-14 opens, in the line of Jos 23:1-2a; 24:1 (and Ant. 5.115b), with Joshua summoning the people to him. As in MT 24:1 and Josephus, the assembly site is identified as "Shechem" rather than the "Shiloh" of LXX 24:1. Diverging from the presentations of both the Bible and Josephus, PseudoPhilo (23.3) interjects a divine appearance to Joshua between the leader's summoning the people (23.1-2) and his words to them (23.4ff) in which the Deity instructs him about what he is to say. ${ }^{40}$ Within Joshua's discourse in 23.4-13 one may distinguish - as in those of 23:2b-16; $24: 2-15$ and $5.115 c-$ 116 - both a retrospective and a hortatory element. The detailed review of God's past dealings with Israel that Philo-Philo attributes to Joshua in 23.4-11 basically corresponds to the historical survey of Jos $24: 2-13,{ }^{41}$ while also contrasting with the highly generalized reference to God's "benefactions" one finds in Ant. 5.115c. The hortatory conclusion to Joshua's speech in 23.12-13 consists of a very brief protasis at the opening of 23.12 ("and now, if you heed your forefathers ..."), followed by an extended apodosis featuring divine promises for the people's life in the land (the remainder of 23.12) and their postmortem future (23.13). Whereas the "eschatological" component of this portion of Joshua's speech has no biblical (or Josephan) parallel, its conditional assurance of a good life on the land draws together elements of both Joshua 23 (see vv 6-8, 11-13, 15-16) as well as still other Scriptural texts (e. g., Dt 4:6-8). ${ }^{42}$ Conversely, just as with the proceeding retrospective, the "Bible-like" expansiveness of Joshua's exhortation in Pseudo-Philo contrasts with Josephus' summary, generalized rendering of this item in 5.116a.

As noted above, Joshua's (second) discourse in 24:2-15 continues with an exchange between him and the people about their serving the Lord (24:16$24)$, and a series of initiatives by the leader $(24: 25-28)$ intended to ensure a

\footnotetext{
${ }^{40}$ Pseudo-Philo likely found inspiration for this interjected theophany and accompanying divine instructions in the messenger formula with which Joshua begins his (second) discourse in Jos 24:2a, i.e. "Thus says the Lord, the God of Israel." Such "prophetic" language presupposes a prior communication by God which Pseudo-Philo supplies in 23.3. (Josephus' Joshua makes no such claim to be speaking in God's name in his discourse of 5.115c-116.)

${ }^{41}$ At the same time Pseudo-Philo also enriches Joshua 24's outline of Israel's history with a variety of elements peculiar to himself; see, e.g., the midrashic elaboration of the "covenant between the pieces" (Gn 15:7-21) in L.A.B. 23.5-7 and the description of the Sinai covenantmaking in 23.10. For more details, see Jacobson (1996, 2:713-26).

${ }^{42}$ For more details, see Jacobson (1996, 2:726-29). Remarkably, Pseudo-Philo's rendition of Joshua's exhortation gives this a completely positive, "upbeat" character, with none of the minatory notes sounded in Joshua 23 or equivalent to Joshua's ironic/sarcastic reminder that the people are free to choose other gods - as in fact they will do shortly afterwards in the time of the Judges - of 24:15.
} 


\section{The demise of Joshua according to Josephus}

permanent record of the people's commitment. Josephus, as was also noted, has no equivalent to this entire sequence. In this regard as well Pseudo-Philo stands closer to the Bible's presentation than does Josephus. At the same time he also gives a highly compressed and (partially) modified rendering of the content of 24:16-28 in 23.14 wherein all attention goes to the people who first pledge to serve the Lord alone (see 24:24) and then, after rejoicing on that day, "made a rededication ceremony for twenty-eight days." 43

In L.A.B. 24.1, some time after the ceremony spoken of in 23.14, Joshua summons a new assembly of the people whom he addresses with words drawn from, e.g., Jos 24:22,27 (the witness motif) and 24:15 (the call to decide between the Lord and other gods, with Joshua and his household opting for the former). In thus attributing a second, distinct speech to Joshua, Pseudo-Philo, here too, aligns himself with the biblical narrative against that of Josephus (who ascribes only a single discourse to Joshua). ${ }^{44}$ To Joshua's renewed address to them, the people respond in 24.2 by expressing the hope that the Lord will account them worthy and then affirm "it is better for us to die in fear of him [the Lord] than to be blotted out from the land," this echoing their protestations of loyalty to the Lord in Jos $24: 16-18,21,24$, but without parallel in Josephus (where the people make no response to Joshua's words of $5.115 \mathrm{c}-116){ }^{45}$

The (second) interaction between Joshua and the people according to Pseudo-Philo concludes in L.A.B. 24.3 as the dying leader blesses and kisses the people, urges them to remember Moses and his covenant, and finally dismisses them. Various elements of this sequence have a basis in Jos 24:2528 (mention of the covenant [25:25a] and the dismissal of the people [25:28]), ${ }^{46}$ but are without counterpart in Josephus.

Pseudo-Philo concludes his rendering of Joshua 23-24 in $24.4-6^{47}$ with a much-expanded version of the death and burial notices of $24: 29-30$. His

\footnotetext{
${ }^{43}$ For more on this sequence, see Jacobson (1996:2.729-30).

${ }^{44}$ On the other hand, whereas in the Bible one has two, back-to back discourses in 23:2b-16 and 24:2-13, Pseudo-Philo derives the content for both the speeches he ascribes to Joshua from Joshua 24, likewise interjecting a period of a least twenty-eight days between the first and second.

${ }^{45}$ On L.A.B. 24.1-2, see Jacobson (1996:2.730-31).

${ }^{46}$ For more on the various biblical sources for Pseudo-Philo's presentation in 24.3, see Jacobson (1996:2.731-32). Pseudo-Philo's explicit mention of the people's "going away" in accordance with Joshua's directive to them has a counterpart in the LXX plus of Jos 24:28. (Similarly, his reference to the Egyptians "persecuting your fathers" in 23.9 is paralleled in LXX Jos 24:5, but not in MT.)

${ }^{47}$ On this sequence, see Jacobson (1996:2.732-35).
} 
expansion of these items does have a certain equivalent in Ant. 5.117-119a where they undergo elaboration as well. The specific content of PseudoPhilo's Ausmalung of 24:29-30 is, however, quite different from Josephus'. Specifically, in 24.4 Joshua, having taken to his bed, addresses Phineas with words of exhortation (Phineas is to "strengthen himself" in view of the people's coming apostasy) and expresses a wish for the prosperity of priesthood and people. Thereafter (24.5), he dies, and his sons place their hands on his eyes. Finally (24.6), the Israelites assembly to bury their leader, pronounce a panegyric over him that includes a reference to his "forty years" of leadership (compare the twenty-five year tenure Josephus attributes to Joshua in $5.117 \mathrm{~b}),{ }^{48}$ bury him "on Mount Ephraim," 49 and then disperse once again. In thus ending his version of Joshua 23-24 with a parallel to 24:29-30, PseudoPhilo leaves aside the series of appended notices of 24:31-33, to which Josephus has at least a partial parallel in 5.119b (the death and burial of Eleazar).

The above, two-sided comparison of L.A.B. 23-24 with both Joshua 2324 and Ant. 5.115-119 makes clear that, in this instance, Pseudo-Philo hews more closely to the biblical story-line than does Josephus. ${ }^{50}$ In particular, whereas Josephus overall significantly abbreviates the Bible's presentation, e.g., compressing its double farewell speech into one, Pseudo-Philo maintains (and amplifies) the expansiveness of the Scriptural narrative, for example, retaining (while also adapting; see $n$ 43) the source duplication of Joshua's final words. Indeed, there is only one case where Josephus' version offers a "positive" parallel to the biblical account that Pseudo-Philo lacks, i.e. mention of Eleazar's death and burial (see 24:33 and 5.119b). Moreover, while Josephus and Pseudo-Philo both take the liberty of interjecting much

\footnotetext{
${ }^{48}$ See also the additional, varying specifications concerning Joshua's tenure elsewhere in Jewish tradition cited in $n$ 25. Pseudo-Philo's ascription of an eulogy for Joshua to the people in 24.6 constitutes an implicit rebuttal of the charge, cited elsewhere in Jewish tradition (see $n$ 28), that the Israelites failed to mourn their leader properly, just as it fills the lacuna, common to both Jos 24:29-30 and Josephus, as to whether the people did pronounce a lament over Joshua.

${ }^{49}$ Pseudo-Philo confines himself to this general indication concerning Joshua's burial place; compare the more expansive localizations given in Jos 24:30 ("in his [Joshua's] own inheritance at Timnath-serah, which is in the hill country of Ephraim, north of the mountain of Gath" and 5.119a ("He was buried in the city of Thamna of the tribe of Ephraim"). In his elaboration of the burial notice of 24:30, Pseudo-Philo does not draw on the attached plus of LXX concerning the stone circumcision knives buried with Joshua.

${ }^{50}$ This, it may be noted, is the reverse of what usually finds when both authors offer a portrayal of some biblical personage or incident. In such cases, it is more common to have Pseudo-Philo recasting the Bible's account in more thorough-going fashion than does Josephus. A case in point is the two writers' handling of the story of Jephthah, his exploits, and (in-) famous sacrifice of his daughter (Jdg 10:6-12:7); see Ant. 5.255-270 and L.A.B. 3940 , respectively.
} 


\section{The demise of Joshua according to Josephus}

additional material into their respective reproductions of Joshua 23-24, their additions do not coincide "positively." 51 In this connection, one might say that in contrast to Josephus who seems concerned not to let the dying Joshua's stature overshadow that of Moses, Pseudo-Philo rather goes beyond the Bible itself in accentuating the former figure's status. ${ }^{52}$

\section{JOSEPHUS AND "THE SAMARITAN CHRONICLE NO. II"}

The other extra-biblical text with which I wish to compare Josephus' version of Joshua 23-24 is the relevant segment (§§ "U-V") of the "Samaritan Chronicle No. II." ${ }^{53}$ As with L.A.B. 23-24, I shall focus on Chronicle's similarities and differences with Ant. 5.115-119 rather than on the Chronicle itself.

The Chronicle's parallel to Joshua 24 is preceded by a version of Jos 22:1-6 ( $\S \mathrm{T}$, the dismissal of the Transjordanian tribes) ${ }^{54}$ and Jos $23: 1$ (the opening of $\S$ “U," Israel's "rest" and Joshua's advanced age). ${ }^{55} \S$ "U" then continues with a rendering of Jos 24:1 (the assembling of the people and leaders at Shechem), adding that those summoned by Joshua ascended Mount Gerizim and presented themselves before God "at the entrance of the tent of meeting."

Next follows the Chronicle's reproduction of Joshua's rehearsal of God's benefits (// 24:2-14). As in Ant. 5.115c-116, but in contrast to MT Joshua (in LXX 24:5 Joshua shifts to referring to God in the third person) and Pseudo-Philo, the Chronicle's Joshua speaks of God in the third person, rather than mediating first-person divine speech. Also comparable to Josephus' rendition is the Chronicle's compression of the biblical historical review from which it omits, for example, the reference to the ancestors' serving other gods (Jos 24:2), the patriarchal succession (24:3-4), and the

\footnotetext{
${ }^{51}$ Elsewhere Josephus and Pseudo-Philo do evidence a range of positive agreements against the Bible itself; see the listing in Feldman (1971:Iviii-Ixi). In our case, Josephus and Pseudo-Philo do agree "negatively" in their common non-reproduction of Jos 24:31 (the people's fidelity during Joshua's lifetime) and 32 (the burial of Joseph's bones).

${ }^{52}$ Thus see, e.g., his inserted reference to the theophany accorded Joshua in L.A.B. 23.3 and the lament over him he attributes to the people in 24.6.

${ }^{53}$ For the Hebrew text of the Chronicle I use Macdonald (1969:29-32) and for the translation (1969:98-100) (In both text and the translation Macdonald supplies the paragraph divisions and sub-divisions and the lettering of these) For the many problems concerning the date of the Chronicle, its relation to the MT, and its peculiar traditions, manuscripts, etc., see Macdonald's (1969:3-74) introduction.

${ }^{54}$ The Chronicle lacks a parallel to the incident of the Transjordanian altar (Jos 22:10-34) that both Josephus and Pseudo-Philo report at length.

${ }^{55}$ Macdonald (1969:98) parallels the opening of $\S U$ with Jos 13:1. In fact, however, that opening with its mention, not only of Joshua's advanced age, but also of Israel's "rest," more closely corresponds to Jos 23:1. In any case, the Chronicle, like Josephus, lacks a parallel to Joshua's initial farewell discourse of 23:2-16, directly juxtaposing Jos (13:1) 23:1 and 24:1.
} 
figure of Balaam (24:9-10). ${ }^{56}$ The Chronicle, in contrast to Josephus (and Pseudo-Philo), does reproduce Joshua's appeal of Joshua 24:14-15, with its call for the people to put away their foreign gods $(v 14)$ and allusion to their alternative option of serving other gods ( $v 15)$ virtually verbatim.

Whereas Josephus has no parallel to the extended sequel to Joshua's speech found in Jos 24:16-28 (exchange between him and the people [vv 1624] and initiatives by Joshua [vv 25-28]), the Chronicle makes selective use of this portion of the biblical chapter. Specifically, the Chronicle reduces the people's four-fold declaration about their readiness to serve the Lord and Joshua's triple response to this of 24:16-24 to an initial statement by the people $(=24: 16-17)$, response by Joshua $(=24: 22 a)$, and concluding assent by the people $(=24: 22 b)$, while omitting, for example, Joshua's affirmation (24:19) about the people's incapacity to serve the Lord. The Chronicle becomes more expansive in its handling of the segment Jos 24:25-28, devoted to the initiatives taken by Joshua following his exchange with the people. From this sequence the Chronicle takes over - with a variety of modifications and/or amplifications - vv 25 (Joshua makes a covenant with the people and gives them "statutes and ordinances at Shechem"), ${ }^{57} 26$ (Joshua "writes these words in the book of the law of the Lord" 58 and erects a great stone "under the oak in the sanctuary of the Lord" ${ }^{29}$ ) and 27a (Joshua's declaration to the people "this stone shall be a witness against us"). The biblical account continues in 24:27b-28 with Joshua expatiating on the witness function of the stone (which has "heard" all the Lord's words to the people and so can serve as a deterrent to their "dealing falsely" with the Lord, v 27a), and then ( $v$ 28) dismissing the people to their inheritances. In place of this concluding complex, the Chronicle substitutes the following notice on a sacrificial/ priestly initiative by the dying Joshua: "He built there (i.e. at the foot of Mt Gerizim] an altar and took a ram and offered it on account of that

\footnotetext{
${ }^{56}$ On the Chronicle's many omissions in its reproduction of the content of Joshua 24, see the remarks of Macdonald (1969:23).

${ }^{57}$ To its concluding mention of "Shechem" drawn from (MT) 24:25 the Chronicle appends the words "which is at the foot of Mount Gerizim, where he (Joshua) had set up a judgment throne."

${ }^{58}$ The Chronicle's rendering of this item adds that Joshua gave the book "to the Levite priests" - an addition likely inspired by Dt 31:9 where, having written "this law," Moses entrusts it "to the priests the sons of Levi." In this instance, the Chronicle enhances the Moses-Joshua parallelism, whereas Josephus, as noted above, seems concerned not to allow Joshua to overshadow his predecessor.

${ }^{59}$ The Chronicle's rendering of Jos $24: 26 \mathrm{~b}$ specifies that the Lord's sanctuary was situated "at the foot of Mount Gerizim".
} 


\title{
The demise of Joshua according to Josephus
}

covenant which the Israelites had made with him."60 To this Sondergut item the Chronicle, at the opening of $\S$ " $\mathrm{V}$," attaches mention of another, final initiative by Joshua, that likewise lacks a biblical counterpart. It runs:

\begin{abstract}
After this Joshua chose twelve princes from the Israelites, and he cast lots over them at the direction of Eleazar the son of Aaron the priest on Mount Gerizim Bethel before the Lord. The lot for kingship over the Israelites came out for a man named Nethanel, the son of Caleb's brother, of the tribe of Judah. ${ }^{61}$ Him he made king over the Israelites.
\end{abstract}

At this juncture, the Chronicle (§ "U") reconnects with the story-line of Joshua 24 in relating the death and burial of Joshua on the basis of its vv 29-30. ${ }^{62}$ Thereafter, it interjects additional Sondergut material that takes the place of the notices of Jos 24:31-32 on the people's fidelity during Joshua's lifetime ( $\mathrm{v}$ 31) and the burial of Joseph's bones. ${ }^{63}$ This inserted elements read: "The Israelites wept for him for thirty days, ${ }^{64}$ and Nethanel the son of Kenaz, who was the son of Caleb's brother, of the tribe of Judah, reigned." Like Josephus (see Ant. 5.119b), the Chronicle concludes its rendition of Joshua 24 with mention of the death and burial of Eleazar (// Jos 24:33) - a happening not mentioned by Pseudo-Philo. Whereas, however, Josephus, following the Bible itself, relates this event in summary fashion, the Chronicle markedly amplifies it. That amplification includes the following items: Eleazar's fifty years of

\footnotetext{
${ }^{60}$ With this covenantal sacrifice compare that initiated by Moses in connection with the Sinai covenant in Ex 24:3-8. The Chronicle's implicit paralleling of Moses and Joshua continues.
}

${ }^{61}$ As Macdonald (1969:99, ad loc.) points out, "Nethanel" here is apparently to be identified with the Judean judge "Othniel" of Jdg 3:7-11. With the Chronicle's foreshadowing here of events of the period of the Judges, compare the LXX plus following Jos 24:33 with its mention of Israel's servitude to Eglom king of Moab (see Jdg 3:12-30). In both Josephus (see Ant. 5.179-184) and Pseudo-Philo (see L.A.B. 25-28) the role of the biblical judge "Othniel" is assumed by his father, i.e. "Kenaz."

${ }^{62}$ The Chronicle goes its own way in its version of the indications concerning Joshua's place of burial given in 24:30 ("in his own inheritance at Timnath-searah, which is in the hill country of Ephraim, north of the mountain of Gaash"). Its notice on the matter reads "And they buried him in Gibeah [the Chronicle presumably derived this place name from Jos 24:33 where the priest Eleazar is buried at this site] which is opposite the chosen place Mount Gerizim Bethel, at Timnath-serah"). The Chronicle has no equivalent to the LXX plus at the end of 24:30, recording the burial alongside Joshua of the circumcision knives. It likewise lacks a counterpart to Josephus' Sondergut notices on the chronology of Joshua's career and the eulogy of him found in Ant. 5.117b-118.

\footnotetext{
${ }^{63}$ The Chronicle's lack of equivalent to these two biblical verses is paralleled in both Josephus and Pseudo-Philo.

${ }^{64}$ This ("non-biblical") mention of the mourning period for Joshua has a noteworthy counterpart in L.A.B. 24.6 (where the words of Israel's lament for him are cited); see nn 28 and 47. The Chronicle's figure corresponds to the duration of the mourning for Moses himself according to Dt 34:8.
} 
priestly service at Mount Gerizim, his covenant-making with the assembled people on Gerizim and sacrificing there, ${ }^{65}$ as the Israelites prostrate themselves before the ark, a procession of the Levites and secular leaders led by the tearful Eleazar that takes them to Gibeah, his son Phineas' town, ${ }^{66}$ where Eleazar renews the covenant, warning his hearers against worshiping other gods or sacrificing elsewhere than on Mount Gerizim, and then proceeds to invest Phineas with his priestly garments, ${ }^{67}$ before finally expiring and being buried "at Gibeah."68

With Ant. 5.115-119 the Chronicle shares, for example, its (virtual) elimination of Joshua's initial farewell discourse (Jos 23), compressed version of the leader's words of 24:2-15 (and third person reference to God throughout this), explicit mention of Phineas' succession to his father (see $n$ 66), and non-reproduction of 24:31-32 (a point both versions have in common also with Pseudo-Philo). At the same time, however, the Chronicle and Josephus markedly diverge in many features of their respective rewritings of Joshua 23-24, with the former, for instance, including a (shortened) rendering of Jos 24:16-28, highlighting the site Mount Gerizim, accentuating the (Moseslike) figures of Joshua and (especially) Eleazar, and introducing the personage of "King Nethanel"-- all elements absent in the Josephan presentation.

\section{CONCLUSION}

Our two-way comparison of Josephus' account of Joshua's end in Ant. 5.115119 has served to bring into sharper focus its distinguishing features vis-à-vis both the biblical presentation and those of Pseudo-Philo and the "Samaritan

\footnotetext{
${ }^{65}$ The dying Eleazar's covenant-making and sacrificing on Gerizim replicates initiatives attributed to the dying Joshua earlier in the Chronicle.

${ }^{66}$ Macdonald (1969:100, ad loc.) points out that this element of the Chronicle's depiction of Eleazar's end has points of contact with the description of Moses' last acts found in the Samaritan document Memar Marqah 5.3. In the Chronicle's presentation then both Joshua and Eleazar are portrayed in terms reminiscent of the figure of Moses. The above processional motif also has a certain counterpart in the LXX plus following Jos 24:33 where, subsequent to Eleazar's burial, the Israelites cause the ark to circulate among them.

${ }^{67}$ This mention of Phineas' succeeding his father has a counterpart in Josephus (Ant. 5.119b) who himself seems to derive the notice from the LXX plus after Jos 24:33; see $n$ 32. For its mention of the transfer of the priestly garments from father to son, the Chronicle is likely inspired by the account of Eleazar's succeeding his father Aaron in Nm 20:22-29.
}

\footnotetext{
${ }^{68}$ To this place name drawn from Jos 24:33, the Chronicle appends the identification "which is opposite the holy mountain, the place which the Lord chose, Mount Gerizim Bethel." The continuation ( $\S$ "W") of the Chronicle following Eleazar's death evidences a certain parallelism with the immediate sequel to Ant. 5.115-120 (see 5.120), both presentations featuring - in contrast to the Bible itself - the leading role assumed by Phineas subsequent to the deaths of his father and Joshua.
} 


\section{The demise of Joshua according to Josephus}

Chronicle No. II." Compared with Joshua 23-24 itself, Josephus' version appears highly "reductionistic," leaving aside, as its does, the whole of Joshua's first discourse of $23: 2 b-16$ and the sequence $24: 16-28$, as well as generalizing and abbreviating the leader's words of 24:2-15. On the other hand, the historian, notwithstanding the brevity of his rendition, does incorporate into this a rather considerable amount of biblically unparalleled material: Joshua's residence at Shechem (5.115a), the conclusion of his speech (5.116b), the chronological data for his career (5.117b), and the eulogy upon him (5.118). As for Ant. 5.115-119 in relation to L.A.B. 23-24 and the Chronicle, we noted that all three versions effectively dispense with Joshua's opening, duplicate discourse of Joshua 23 - although Pseudo-Philo does have the hero deliver two distinct speeches, each of which draw on elements present in Joshua in 24:2-24. All three presentations likewise either pass over entirely or significantly abbreviate the highly repetitious exchange between people and Joshua of 24:16-24 (eliminating, e. g., the leader's problematic claim [24:19] about the Israelites' inability to serve the Lord), just as they dispense with the somewhat extraneous notices of 24:31-32. ${ }^{69}$ On the other hand, neither Pseudo-Philo nor the Chronicle has a counterpart to Josephus' Sondergut in 5.115-119, even as he, for example, lacks a equivalent to the theophany peculiar to L.A.B. 23.3 or the lengthy catalogue of events surrounding the death of Eleazar that is unique to the Chronicle's $\S$ "V." In addition, whereas Josephus seems intent on diminishing the role and actions of the dying Joshua lest he overshadow the departing Moses, the other two presentations of Joshua's demise evidence rather the opposite tendency. In sum, when compared with both the biblical story and its retellings in L.A.B. and the Chronicle, Josephus' rendition emerges as a distinctive link within a multi-century chain of narrative and commentary concerning the hero's end that has continued down until today.

\section{Works consulted}

Begg, C T 1993. Josephus' account of the early divided monarchy (AJ 8, 212-420). Leuven: University Press. (Bibliotheca Ephemeridum Theologicarum Lovaniensium 108.)

Begg, C T 1997. The transjordanian altar (Jos 22:10-34) according to Josephus (Ant. 5.100-114) and Pseudo-Philo (LAB 22.1-8). Andrews University Seminary Studies 35, 5-18.

Begg, C T 2005. Flavius Josephus Judean Antiquities 5-7. Leiden: Brill. (Flavius Josephus Translation and Commentary 4.)

\footnotetext{
${ }^{69}$ Another communality among Ant. 5.115-119, L.A.B. 23-24 and the Chronicle is that they all, in varying degrees, evidence points of contact with both the MT and LXX text-forms of Joshua (23-)24.
} 
Brooke, A E \& Maclean, N 1917. The Old Testament in Greek I:IV Joshua, Judges and Ruth. Cambridge: University Press.

Dietzbfelbinger, C 1975. Pseudo-Philo: Antiquitates Biblicae (Liber Antiquitatum Biblicarum.) Gütersloh: Gütersloher Verlagshaus. (Jüdische Schriften aus hellenistisch-römischer Zeit II:2.)

Feldman, L H 1971. Prologomenon in James, M R, The Biblical Antiquities of Philo. New York: Ktav. (The Library of Biblical Studies.)

Feldman, L H 1998. Josephus's interpretation of the Bible. Berkeley, CA: University of California Press.

Feldman, L H 2002. The portrayal of Phineas by Philo, Pseudo-Philo and Josephus. Jewish Quarterly Review 92, 315-45.

Goodblatt, D 1994. The monarchic principle: Studies in Jewish self-government in antiquity. Tübingen: Mohr Siebeck. (Texte und Studien zum antiken Judentum 38.)

Harrington, D J, Perrot, C \& Bogaert, P M 1976. Pseudo-Philon Les Antiquités Bibliques, 2 vols. Paris: Cerf. (Sources chrétiennes 229-230.)

Jacobson, H 1996. A commentary on Pseudo-Philo's Liber Antiquitatum Biblicarum, 2 vols. Leiden: Brill. (Arbeiten zur Geschichte des antiken Judentums und des Urchristentums 31.)

Macdonald, J 1969. The Samaritan chronicle no. II (or: Sepher Ha-Yamim) from Joshua to Nebuchadnezzar. Berlin: De Gruyter. (Beihefte zur Zeitschrift für die alttestamentliche Wissenschaft 107.)

Marcus, R 1934. Josephus V: Jewish antiquities, books V-VIII. Cambridge, MA: Harvard University Press. (Loeb Classical Library.)

Mason, S 2003. Flavius Josephus in Flavian Rome: Reading between the lines, in Boyle, A J \& Dominik W J (eds.), Flavian Rome: Culture, image, text, 559-90. Leiden: Brill.

Moatti-Fine, J 1996. Jésus (Josué). Paris: Cerf. (La Bible d'Alexandrie 6.)

Murphy, F J 1993. Pseudo-Philo: Rewriting the Bible. New York: Oxford University Press.

Nodet, E 1995. Flavius Jos.phe III: Les Antiquités Juives Livres IV et V. Paris: Cerf. Noth, M 1981. The Deuteronomistic history. Sheffield: JSOT Press.

Reinmuth, E 2002. Zwischen Investitur und Testament: Beobachtungen zur Rezeption des Josuabuches im Liber Antiquitatum Biblicarum. Scandinavian Journal of the Old Testament 16, 24-43.

Robert, U 1900. Heptateuchi Partis Posterioris Versio Latina Antiquissima e Codice Lugduensi. Lyon: Rey et $\mathrm{C}^{\text {ie }}$.

Rösel, M 2002. The Septuagint-Version of the Book of Joshua. Scandinavian Journal of the Old Testament 16, 5-23.

Rofé, A. 1982. The end of the book of Joshua according to the septuagint. Henoch 4, 17-36.

Spilsbury, P 1998. The image of the Jew in Flavius Josephus' paraphrase of the Bible. Tübingen: Mohr Siebeck. (Texte und Studien zum antiken Judentum 69.) 